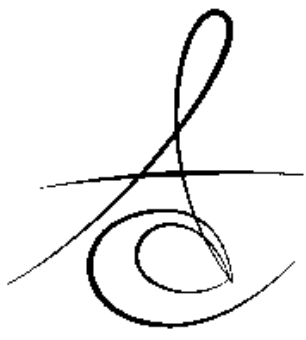

\title{
EFFECT OF DIFFERENT SURFACE TREATMENT ON BOND STRENGTH OF RESIN CEMENT TO ZIRCONIUM AND LEUCITE-REINFORCED GLASS CERAMIC ${ }^{\neq}$
}

\author{
ZİRKONYUM VE LÖSİTLE GÜÇLENDİRİLMİŞ CAM SERAMİKLERİN REZİN \\ SİMANLA BAĞLANMA DAYANIMINA FARKLI YÜZEY İŞLEMLERİNİN ETKİSİ ${ }^{*}$
}

\author{
Dr. Öğr. Üy. Hatice ÖZDEMİR*
}

Prof. Dr. Funda BAYINDIR*

Makale Kodu/Article code: 2798

Makale Gönderilme tarihi: 16.04.2016

Kabul Tarihi; 08.06.2016

\section{ABSTRACT}

Aim: The aim of this study was to determine shear bond strength of resin cement to zirconium and leucite-reinforced glass ceramic after different surface treatment.

Materials and Methods: A total of 50 discs of zirconium and leucite-reinforced glass ceramic were prepared (10 mm in diameter and $1 \mathrm{~mm}$ in thickness) according to the manufacturer's instructions. Specimens were embedded in self-cure acrylic resin blocks. Specimens were divided into five groups randomly $(n=5)$, and the following treatments were applied: 1 . Air abrasion with aluminium-oxide particles $(50 \mu \mathrm{m}), 2$. Acid etching with $9,5 \%$ hydrofluoric acid, 3. Co-jet, 4. Nd:YAG laser irradiation (1 mm distance, $100 \mathrm{~mJ}, 20 \mathrm{~Hz}, 2 \mathrm{~W}$ ) and 5. Er:YAG laser irradiation (1 $\mathrm{mm}$ distance, $400 \mathrm{~mJ}, 20 \mathrm{~Hz}, 8 \mathrm{~W}$ ). After the surfacetreatment methods, Panavia $\mathrm{F}$ dual-cure resin cement were applied on the specimens. All the specimens were subjected to a shear test to evaluate their bond strengths. The data were analyzed with one-way variance analysis (ANOVA).

Results: In the leucite-reinforced glass ceramic specimens, the highest bonding values $(12.06 \pm 1.4)$ was obtained in $\mathrm{HF}$ acid group. In the zirconium specimens, the highest bonding values $(9.7 \pm 4.05)$ was obtained in CoJet group. However, adhesive failures were obtained in these groups. But, cohesive failures were obtained commonly in Co-jet groups.

Conclusions: The in vitro findings from this study indicate that surface-treatment procedures applied to leucite-reinforced glass ceramic and zirconium are important to bond strength of resin cement.

Keywords: Zirconium, leucite-reinforced glass ceramic, resin cement öz

Amaç: Bu çalışmanın amacı, farklı yüzey işlemlerinden sonra rezin simanın zirkonyum ve lösitle güçlendirilmiş cam seramiklerle olan makaslama bağlanma dayanımını değerlendirmektir.

Gereç ve Yöntem: Zirkonyum ve lösitle güçlendirilmiş cam seramikten toplamda 50 tane disk şeklinde (10 mm çap ve $1 \mathrm{~mm}$ kalınlığında) örnekler üretici talimatlarına uygun olarak hazırlandı. Örnekler self-cure akrilik rezine gömüldü. Örnekler rastgele 5 gruba ayrıldı ve şu yüzey işlemleri uygulandı: 1. Alüminyum oksit tozu ile kumlama $(50 \mu \mathrm{m})$, 2. \% 9.5' lik hidroflorik asit ile pürüzlendirme, 3. Co-Jet, 4. $\mathrm{Nd}$ :YAG lazer uygulaması (1mm mesafeden, $100 \mathrm{~mJ}$, $20 \mathrm{~Hz}, 2 \mathrm{~W})$, 5. Er:YAG lazer uygulaması (1mm mesafeden, $400 \mathrm{~mJ}, 20 \mathrm{~Hz}, 8 \mathrm{~W}$ ). Yüzey işlemlerinden sonra, örneklerin üzerine Panavia $F$ dual-cure rezin siman yerleştirildi. Tüm örneklere bağlanma dayanımlarını değerlendirmek için makaslama testi uygulandı. Elde edilen sonuçlar tek yönlü Varyans analizi ile değerlendirildi.

Bulgular: Lösitle güçlendirilmiş cam seramik örneklerde en yüksek bağlanma dayanımı değerleri (12.06 \pm 1.4$)$ hidroflorik aist uygulanan grupta, zirkonyum örneklerde $(9.7 \pm 4.05)$ ise Co-Jet uygulanan örneklerde belirlendi. Ayrıca, bu gruplarda adeziv kopmalar gözlemlendi. Fakat koheziv kopmalar yaygın olarak Co-Jet uygulanan gruplarda gözlemlendi.

Sonuç: Bu in-vitro çalışmanın bulguları zirkonyum ve lösitle güçlendirilmiş cam seramiklere uygulanan yüzey işlemlerinin rezin simanla olan bağlanma dayanımında önemli olduğunu göstermiştir.

Anahtar Kelimeler: Zirkonyum, lösitle güçlendirilmiş cam seramik, rezin siman

\footnotetext{
* Atatürk Üniversitesi Diş Hekimliği Fakültesi Protetik Diş Tedavisi Anabilim Dalı, Erzurum

${ }^{\ddagger}$ This study presented at the First International Dentistry Congress of İnönü University, Malatya, Turkey, April 2012
}

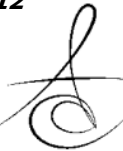




\section{INTRODUCTION}

Ceramics are still the most aesthetically pleasing existing materials in restorative dentistry. Although physical properties are good, biological and aesthetic compatibility can not be provided in metalceramic systems. ${ }^{1,2}$ Metal-ceramic systems has proven the success of crown and bridge restorations. However, together with the icrease of interest in aesthetic dentistry, development of alternatives of metalceramic restorations rapidly continuing. ${ }^{3}$ Compared to metal-ceramic restorations, today full-ceramic restorations have been preferred more because of their aesthetic features and better biological features. Upon increasing aesthetic needs of people, use of porcelain restorations in posterior teeth has been vurrent issue. As an alternative to restorative techniques whose success has been proven for many years, new techniques are being developed every day. ${ }^{4}$

Ceramic is one of widely used materials in dentistry because of their inertness, color stability, high abrasion resistance, low thermal conductivity, biocompatibility and aesthetic properties. ${ }^{5,6}$ Thermal conductivity and thermal expansion coefficient are very close to the values of enamel and dentin. High resistance against the pressures (350-550 $\mathrm{MPa}$ ) but very low resistance to stress (20-60 MPa) ceramics' biggest disadvantage is easy fractures. Though fully successful results as metal becked porcelain are not taken in clinical trials, studies about all ceramics are being carried on. ${ }^{5,7-11}$ Compared with materials that have normal resistance distribution values, ceramic shows asymmetric resistance distribution and seen to be able to be broken under any force of maximum resistance value. ${ }^{12}$ Unsupported ceramic materials are susceptible to breakage under tensile forces. Metal casting infrastructure provide ceramics with excellent mechanical support but form aesthetic problems. ${ }^{8}$ Today, depending on progress in technology and materials, ceramic restorations are able to be cemented with adhesive systems and so ceramic restoration is reinforced by providing direct force transmission from restoration to tooth. ${ }^{8}$ One of the techniques of strenghtening ceramic is to use infrastructures that are in color of tooth and more resistant to stretch instead of casting metal infrastructures. Studies on ceramic core structure have been carried out in order to strengthen ceramic, as well. ${ }^{12}$
Physical and chemical properties of dental ceramics have been tried to be improved by oxide added in their structure. ${ }^{7}$ This new glass-ceramics, generally known also as oxide ceramics, are based on crystallized zirconium, magnesium or aluminum. ${ }^{6}$ Zirconium has been begun to be used within porcelain material in dentistry due to its low grain diameter and high tensile strenght. ${ }^{4}$ Optimum physical properties such as high flexural strength, and fracture toughness make convensional cements possible to use for zirconia-base crowns and FPD. But if zirconiabase systems are going to be used to restorate teeth with retention problems caused by short crown lengths, advantages of adhesive cementation can be useful. ${ }^{13}$

Clinical success of full ceramic restorations pasted with conventional cements reduces, also the microleakage seen in conventional cementation causes staining in crowns. ${ }^{14}$ Resin cements have been widely used in recent years due to the fact that they icrease the mechanical resistance of restorations and prevent microleakage. ${ }^{15-17}$ Mechanical retention provided by surface procedures is the most important factor for sufficient bonding. ${ }^{18}$ Recent studies show that there are problems about bonding in full ceramic restorations and in order to eliminate these problems, surface properties of ceramic materials are changed and bonding is being tried to be enhanced. ${ }^{18,19-26}$ Though there are trails that show the effects of different surface treatments in various ceramics, there is no consensus about the best surface procedure that provide optimal bonding resistance as bound to cement and ceramic used in literature. ${ }^{27}$

Purpose of this study is to evaluate the bonding of resin cement to leucite-reinforced glass ceramic and zirconium applied different surface procedures.

\section{MATERIALS AND METHODS}

The materials used in this study are shown in Table 1. $10 \mathrm{~mm}$ in diameter and $2 \mathrm{~mm}$ thick in accordance with the manufacturer's instructions 25 each samples were prepared from zirconium and leucite-reinforced glass ceramic for this study. Samples were embedded in self-cure acrylic resin to be $12 \mathrm{~mm}$ in diameter and $6 \mathrm{~mm}$ in length. Respectively 300 -, 600 -, $800-, 1000$ - and 1200 -of grit SiC abrasives were apllied on sample surfaces. Samples were allowed to stand in ultrasonic cleaner filled with 
distilled water for $5 \mathrm{~min}$.

Table 1. Materials used in this study

\begin{tabular}{|c|c|c|}
\hline Material & Manufacturer & Lot number \\
\hline Zirconium & $\begin{array}{c}\text { Kuraray Noritake Dental } \\
\text { Inc. }\end{array}$ & 054256 \\
\hline $\begin{array}{c}\text { Leucite-reinforced } \\
\text { glass ceramic }\end{array}$ & $\begin{array}{c}\text { IPS Empress, Ivoclar } \\
\text { Vivadent }\end{array}$ & 507664 \\
\hline $\begin{array}{c}\text { Resin cement (Dual- } \\
\text { cure) }\end{array}$ & $\begin{array}{c}\text { Panavia F 20, Kuraray, } \\
\text { Japan }\end{array}$ & 041332 \\
\hline Acid (\% 9.5 HF gel) & Bisco, BISDENT, USA & 1100008120 \\
\hline
\end{tabular}

Samples were divided into 5 groups randomly according to surface procedures to be applied. Surface procedures applied samples;

1. Acid etching (A group): $9.5 \% \mathrm{HF}$ acid was applied on sample surfaces for $20 \mathrm{sec}$. They were washed with pressured water for 20 seconds in order to remove acid and then dried.

2. Sandblasting (S group): thay were sandblasted with fine-tipped sandblasting device (Macro Cab, Great Lakes Dental Products, USA) and $50 \mu \mathrm{m}$ particle size of Al2O3 sand under atmospheric air pressure from a distance of approximately $1 \mathrm{~cm}$ for $20 \mathrm{sec}$.

3. Co-jet ( $\mathrm{C}$ group): $30 \mu \mathrm{m}$ particle size of salinized $\mathrm{Al}_{2} \mathrm{O}_{3}$ sand was applied with intraoral air-abrasion device and pressure of 30 psi from a distance of 1 $\mathrm{cm}$ for $15 \mathrm{sec}$.

4. Er-Yag laser (E group): Laser was applied from a distance of $1 \mathrm{~mm}$ for 20 seconds with water-cooling on Er-Yag laser unit (Smart, DEKA, Italy). Laser parameters: $400 \mathrm{~mJ}, 20 \mathrm{~Hz}, 8 \mathrm{~W}$.

5. Nd-Yag laser ( $\mathrm{N}$ group): Laser was applied from a distance of $1 \mathrm{~mm}$ for 20 seconds with water-cooling on Nd-Yag laser unit (Smartlife, DEKA, Italy). Laser parameters: $100 \mathrm{~mJ}, 20 \mathrm{~Hz}, 2 \mathrm{~W}$.

After applying surface procedures, samples were cleaned with distilled water in ultrasonic cleaner for 5 minute. SEM analysis was made a samples from each group to see changes that occured on sample surfaces as a result of surface procedures and SEM images were obtained. Dual-cure resin cement (Panavia-F) was applied on samples' surfaces (4 $\mathrm{mm}$ in diameter and $2 \mathrm{~mm}$ height) and polymerized with light.

Samples were respectively placed in a universal testing device to evaluate the resin cement bonding to zirconium and leucite-reinforced glass ceramic samples and the shear force was applied until the break and seperation occurred.

Data were analyzed by Analysis of Variance using SPSS package program (IBM SPSS for Windows, version 20.0) (Table 4)

\section{RESULTS}

Means and standard deviations of the samples are shown in Table. 2. C group showed the highest fracture value while the $\mathrm{N}$ group showed the lowest fracture value among leucite-reinforced glass ceramic and zirconium samples.

Table 2. Means and standard deviations of groups

\begin{tabular}{|l|l|l|l|}
\hline & $\begin{array}{l}\text { Surface } \\
\text { treatment }\end{array}$ & Mean & $\begin{array}{l}\text { Std. } \\
\text { Deviation }\end{array}$ \\
\hline \multirow{4}{*}{ Zirconium } & Acid etching & 8,30 & 2,62 \\
\cline { 2 - 4 } & Co-jet & 9,70 & 4,05 \\
\cline { 2 - 4 } & Sandblasting & 9,22 & 4,81 \\
\cline { 2 - 4 } & Er:YAG laser & 7,56 & 4,50 \\
\cline { 2 - 4 } & Nd:YAG laser & 7,24 & 1,74 \\
\hline \multirow{3}{*}{$\begin{array}{l}\text { Leucite- } \\
\text { glainforced }\end{array}$} & Acid etching & 9,98 & 6,37 \\
\cline { 2 - 4 } & Co-jet & 12,06 & 1,40 \\
\cline { 2 - 4 } & Sandblasting & 9,46 & 3,27 \\
\cline { 2 - 4 } & Er:YAG laser & 6,22 & 2,12 \\
\cline { 2 - 4 } & Nd:YAG laser & 6,02 & 0,46 \\
\hline
\end{tabular}

Whether there are differences between groups were evaluated with variance analysis. (Table. 3) In the analysis result, while no significant differences were observed depending on the material, the difference between groups were observed significantly ( $p<0.05)$ as a result of surface procedures. In addition, interaction between surface procedure and material was not significant.

Table 3. Results of ANOVA

\begin{tabular}{|l|l|l|l|l|}
\hline & df & \multicolumn{1}{|c|}{$\begin{array}{c}\text { Mean } \\
\text { Square }\end{array}$} & \multicolumn{1}{|c|}{ F } & \multicolumn{1}{|c|}{ Sig. } \\
\hline Material & 1 & 0,650 & 0,051 & 0,823 \\
\hline Surface treatment & 4 & 30,596 & 2,397 & 0,04 \\
\hline Inter- action & 4 & 7,837 & 0,614 & 0,655 \\
\hline
\end{tabular}

Fracture types that accured after the share force had been applied were shown in Table. 4. According to this, the most observed fracture in all samples is adhesive fractures. In addition, cohesive fractures were observed more in both zirconium and 
leucite-reinforced glass ceramic samples applied Cojet. Adhesive fractures occured completely in all samples applied laser.

Table 4. Number of the failure types after the shear

\begin{tabular}{|l|l|l|l|}
\hline \multicolumn{4}{|c}{ test } \\
\hline \multirow{4}{*}{$\begin{array}{l}\text { Leucite- } \\
\text { reinforced } \\
\text { glass } \\
\text { ceramic }\end{array}$} & $\begin{array}{c}\text { Surface } \\
\text { treatment }\end{array}$ & Adhesive & $\begin{array}{c}\text { Cohesive } \\
\text { (Cement) }\end{array}$ \\
\cline { 2 - 4 } & Co-jet & - & 2 \\
\cline { 2 - 4 } & Sandblasting & 3 & 5 \\
\cline { 2 - 4 } & Er:YAG laser & 5 & - \\
\cline { 2 - 4 } Zirconium & Nd:YAG laser & 5 & - \\
\cline { 2 - 4 } & Acid etching & 4 & 1 \\
\cline { 2 - 4 } & Co-jet & 1 & 4 \\
\cline { 2 - 4 } & Sandblasting & 4 & - \\
\cline { 2 - 4 } & Er:YAG laser & 5 & - \\
\cline { 2 - 4 } & Nd:YAG laser & 5 & - \\
& & & \\
\hline
\end{tabular}

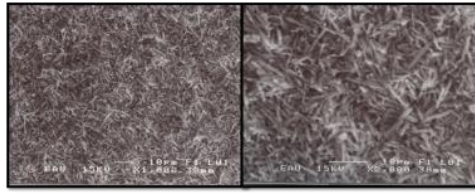

(a)
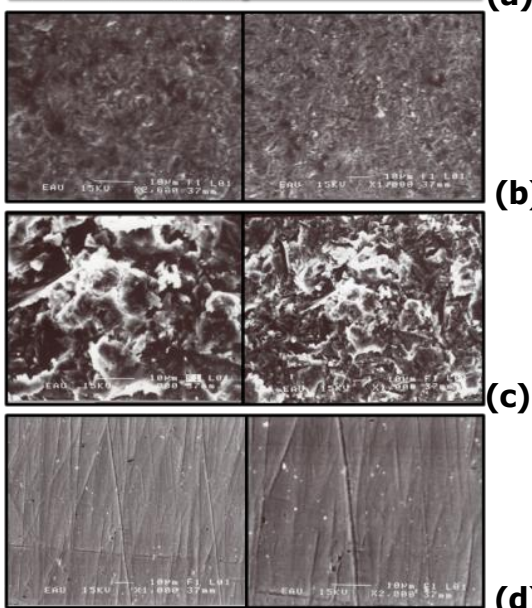

(c)

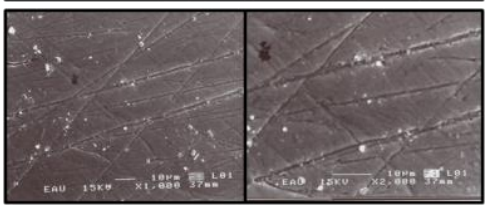

(d)

(e)

Figure 1. SEM observation of the IPS Empress ceramic after surface treatments at $\times 1000$ and $\times 2000$ magnification and bar marker indicate $10 \mu \mathrm{m}$. (a), hydrofluoric acid (9,5\%) etching; (b), Co-jet (silanized $\mathrm{Al}_{2} \mathrm{O}_{3}$ with $30 \mu \mathrm{m}$ particle size); (c), sandblasting $\left(\mathrm{Al}_{2} \mathrm{O}_{3}\right.$ with $50 \mu \mathrm{m}$ particle size); (d), $\mathrm{Er}$ Yag laser application; (e), Nd-Yag laser application.

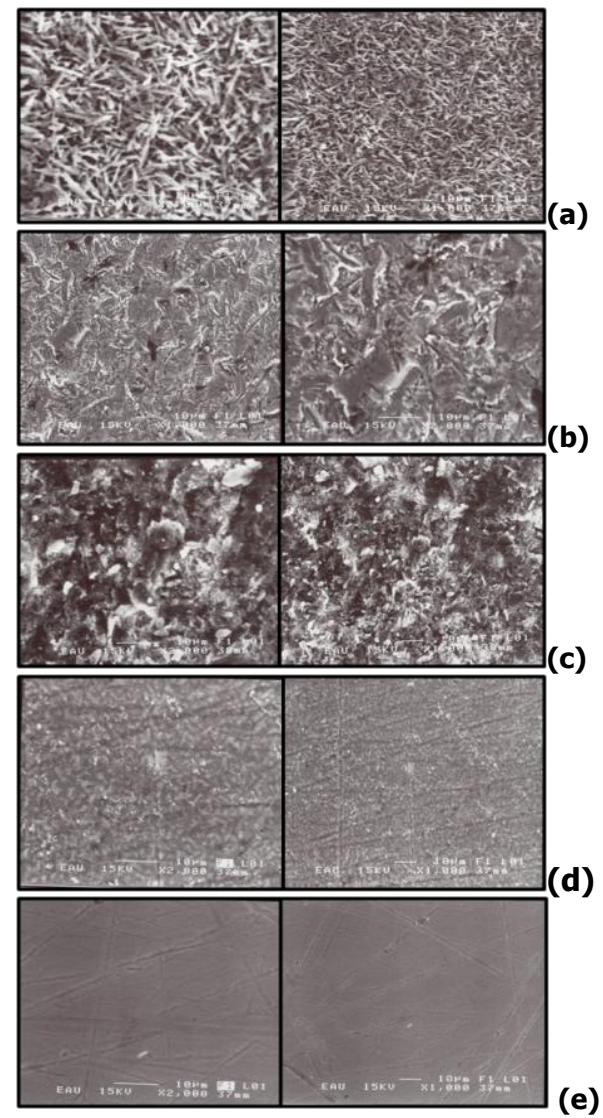

Figure 2. SEM observation of the Zirconium after surface treatments at $\times 1000$ and $\times 2000$ magnification and bar marker indicate $10 \mu \mathrm{m}$. (a), hydrofluoric acid (9,5\%) etching; (b), Co-jet (silanized $\mathrm{Al}_{2} \mathrm{O}_{3}$ with $30 \mu \mathrm{m}$ particle size); (c), sandblasting $\left(\mathrm{Al}_{2} \mathrm{O}_{3}\right.$ with $50 \mu \mathrm{m}$ particle size); (d), Er-Yag laser application; (e), Nd-Yag laser application.

\section{DISCUSSION}

In the present study, $\mathrm{C}$ group showed the highest bond strength values in both zirconium and leucite-reinforced glass ceramic samples. $\mathrm{N}$ group showed the lowest bond strength values in both sample group.

Bond strength between ceramic surface and resin are based on micromechanical and chemical coupling that provide surface cleanliness and roughness. Several pre-processing procedure has been recommended and being used clinically in order to create micromechanical retentive ceramic surface. ${ }^{28-32}$ Etching with HF acid solution can provide suitable surface properties and roughness. ${ }^{29-32} \mathrm{HF}$ acid provides roughness by dissolving glass phase and crystals on ceramic surface. ${ }^{33-39}$ Estafen et al. ${ }^{40}$ reported a good bond strenght in leucite-reinforced

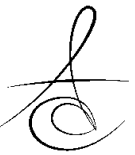


glass ceramic samples applied $9.6 \% \mathrm{HF}$ acid for 60 seconds if microhybrid composite resin was used. In the present study as well, the highest bonding values were observed in $\mathrm{H}$ group after $\mathrm{C}$ group in leucitereinforced glass ceramic samples. According to the Neis et al. ${ }^{41}$ surface treatments (tribochemical, sandblasting, acid etching and burning) effect of micro tensile bond stregth of feldspathic, lithium disilicatereinforced and leucite-reinforced ceramics.

Lacy et al. ${ }^{42}$ showed that sandb- lasting provided sufficient bonding strenght. Kara et al. ${ }^{43}$ reported that the samples applied sandblasting showed maximum surface roughness in their study. In the present study, the highest bonding values were observed in $\mathrm{S}$ group after $\mathrm{C}$ group among zirconium samples. Also, the highest bonding values among leucite-reinforced glass ceramic samples were observed in $\mathrm{S}$ group after $\mathrm{H}$ and $\mathrm{C}$ group.

Er: YAG laser affects tooth tissues by means of termomechanical melting. ${ }^{44}$ Changes on ceramic surface are also based on the caremic that is used together with energy density in laser application. ${ }^{45} \mathrm{Nd}$ : YAG laser application is recommended to modify ceramic surfaces. ${ }^{46}$ Shiu et al. ${ }^{45}$ observed that $1 \mathrm{~W}$ power of Er: YAG laser applied feldspathic ceramic did not provide sufficient ruoghness connected with ceramic content. In the present study, $\mathrm{N}$ group showed the lowest bonding values after $\mathrm{E}$ group.

Akyl et al. ${ }^{39}$ found that the Er:YAG laser irradiation increased the resin cement bond strength to zirconium-oxide ceramic. In contrast with Akyll et al. ${ }^{39}$ findings, Stübinger et al. ${ }^{47}$ observed that the Er:YAG laser at power output $10 \mathrm{~W}$ was not effective on Y-TZP surfaces. They concluded that the Er:YAG laser should not be recommended for the Y-TZP material because it could be emitted from the opposite surface. Likewise, Cavalcanti et al. ${ }^{48}$ found that Er:YAG laser irradiation at $200 \mathrm{~mJ} /$ pulse, $10 \mathrm{~Hz}$, for $5 \mathrm{sec}$ on YTZP surfaces provided a mild surface alteration effect between air abrasion with aluminum oxide and higher laser energies ( 400 and $600 \mathrm{~mJ} /$ pulse, $10 \mathrm{~Hz}$ ). They concluded that Er:YAG laser irradiation at this power setting was a potential method of surface treatment for Y-TZP material. However, another study by Cavalcanti et al. ${ }^{48}$ stated that an Er:YAG laser irradiation power setting of $200 \mathrm{~mJ} /$ pulse, $10 \mathrm{~Hz}$ for $5 \mathrm{sec}$ did not improve the bond strength as well as air abrasion and it decreased the bond strength compared to that of untreated surface. Akyl et al. ${ }^{39}$ it was found that Nd:YAG laser irradiation decreased the bond strength compared to that of untreated material. In the present study, laser irridation decreased the bond strength compared with the CoJet system.

Determining fracture types and analysing them are very important in bonding tests. ${ }^{38}$ In our study in $90 \%$ of the samples applied Co-jet, cohesive fractures were observed within resin cement while adhesive fractures were mainly observed in other sample groups. Also, $100 \%$ of adhesive fractures were identified in all samples applied the Nd: YAG and Er: YAG laser.

\section{CONCLUSION}

Different surface treatment presented different changes on surface of substructure materials. While application of Co-Jet showed high bond strength between leucite-reinforced glass ceramic and resin cement, sandblasting showed high bond strength between zirconium and resin cement. Laser application had insignificant effect on bond strength of resin cement to both materials.

Hatice ÖZDEMİR, ORCID ID: 0000-0001-8512-0471

Funda BAYINDIR, ORCID ID : 0000-0001-5699-2879

\section{REFERENCES}

1. Nakamura S, Yoshida K, Kamada K, Atsuta M. Bonding between resin luting cement and glass infiltrated alumina-reinforced ceramics with silane coupling agent. J Oral Rehabil 2004;31:785-93.

2. Kiyan VH, Saraceni $\mathrm{CH}$, da Silveira BL, Aranha AC, Eduardo $C d a P$. The influence of internal surface treatments on tensile bond strength for two ceramic systems. Oper Dent 2007;32:457-65.

3. Guess PC, Andreja Kulis A, Witkowski S, Wolkewitz $M$, Zhang $Y$, Strub JR. Shear bond strengths between different zirconia cores and veneering ceramics and their susceptibility to thermocycling. Dent Mater 2008;24:1556-67.

4. Paolo FM, Pierfrancesco RI, Luca R. An overview of zirconia ceramics; Basic properties and clinical applications. J Dent 2007;35:819-26.

5. Lawn BR, Deng Y, Lloyd IK, Janal MN, Rekow ED, Thompson VP. Materials Design Of Ceramic- Based Layer Structures For Crowns. J Dent Res 2002;81:433-8. 
6. Vult $\mathrm{P}$, Von Steyern, Carlson $\mathrm{P}$, Nilner K. AllCeramic Fixed Partial Dentures Designed According To The DC-Zirkon Technique: A 2-Year Clinical Study. J Oral Rehabil 2005;32:180-7.

7. Dental Materials Science. 2nd ed. Cork Universty Press. 1993. p. 112-120.

8. Qualtrough AJE, Piddock V. Ceramic Update. J Dent 1997;25:91-5.

9. Haselton DR,Diaz-Arnold A, Hillis SL. Clinical assessment of high-strenght all-ceramic crowns J. Prosthet Dent 2000;83:396-401.

10. Kern M. Bond strength of luting cements to zirconium oxide ceramics. Int J Prosthodont 2000;13:350.

11. Lawn BR, Deng Y, Thompson VP. Use of contact testing in the characterization and design of allceramic crown like layer structures: A review. J Prosthet Dent 2001;86:495-510.

12. Tinscherta J, Zweza D, Marxa R, Anusaviceb K J. Structural Reliability Of Alumina-, Feldspar,Leucite-, Mica- And Zirconia-Based Ceramics. ] Dent 2000;28:529-35.

13. Aksoy İ, Varol S, Özkan Y. Zirkonyum restorasyonların simantasyonu. Ata Üniv Diş Hek Fak Derg. 2012;Suppl 6:124-31.

14. Blatz MB, Sadan A, Kern M. Resin-ceramic bonding: a review of the literature. J Prosthet Dent 2003;89:268-74.

15. Peumans $M$, Van Meerbeek B, Lambrechts $P$, Vanherle G. Porcelain veneers: a review of the literature. J Dent 2000;28:163-77.

16. Kern M, Thompson VP. Sandblasting and silica coating of a glass-infiltrated alumina ceramic: volume loss, morphology and changes in the surface composition. J Prosthet Dent 1994;7:45361.

17. Shopr AM, Sobrino LC, Consani S, Sinhoreti M, Knowles JC. Influent of surface conditions and silane agent on the bond of resin to IPS Empress 2 ceramic. Int J Prosthodont 2003;16:277-82.

18. Nagayassu MP, Shintome LK, Uemura ES, Araujo JEJ. Effect of surface treatment on the shear bond strength of a resin-based cement to porcelain. Braz Dent J 2006;17:290-5.

19. Shopr AM, Sobrino LC, Consani S, Sinhoreti M, Knowles JC. Influent of surface conditions and silane agent on the bond of resin to IPS Empress 2 ceramic. Int J Prosthodont 2003;16:277-82.
20. Shahverdi S, Canay S, Sahin E, Bilge A. Effect of different surface treatment methods on the bond strength of composite resin to porcelain. J Oral Rehabil 1998;25:699-705.

21. Pisani-Proenca J, Erhardt MC, Valandro LF, et al. Influence of ceramic surface conditioning and resin cements on micro tensile bond strength to a glass ceramic. J Prosthet Dent 2006;96:412-8.

22. Madani M, Chu FC, McDonald AV, Smales RJ. Effect of surface treatment on shear bond strength between a resin cement and an alumina core. J Prosthet Dent 2000;83:644-50.

23. Bona AD, Donassollo TA, Demarco FF, Barrett $A A$, Mecholsky Jr JJ. Characterization and surface treatment effects on topography of a glassinfiltrated alumina/zirconiareinforced ceramic. Dent Mater 2007;23:769-75.

24. Retief HD. Standardizing laboratory test. Am J Dent 1991;4:231-6.

25. Özcan M, Alkumru H, Gemalmaz D. The effect of surface treatment on the shear bond strength of luting cement to a glass-infiltrated alumina ceramic. Int J Prosthodont 2001;14:335-43.

26. Özcan M, Vallittu PK. Effect of surface conditioning methods on the bond strength of luting cement to ceramics. Dent Mater 2003;19:725-31.

27. Kamada K, Yoshida K, Atsuta M. Effect of ceramic surface treatments on the bond of four resin luting agents to a ceramic material. J Prosthet Dent 1998;79:508-13.

28. Sorensen JA, Engelman MJ, Torres TJ, Avera SP. Shear bond strength of composite resin to porcelain. Inter J Prosthodont 1991;4:17-23.

29. Bailey LF, Bennet RJ. DICOR surface treatments for enhanced bonding. J Dent Res 1988;67:92531.

30. Wolf DM, Powers JM, O'Keefe KL. Bond strength of composite to porcelain treated with new porcelain repair agents. Dent Mater 1992;8:158-61.

31. Chen JH, Matsumura $H$, Atsuta M. Effect of different etching periods on the bond strength of a composite resin to a machinable porcelain. J Dent 1998;26:53-8.

32. Chen JH, Matsumura $\mathrm{H}$, Atsuta. Effect of etchant, etching period, and silane priming on bond strength to porcelain of composite resin. Oper Dent 1998;23:250-7. 
33. Li R, Ren Y, Han J. Effects of pulsed Nd:YAG laser irradiation on shear bond strength of composite resin bonded to porcelain. Hua Xi Kou Qiang Yi Xue Za Zhi 2000;18:377-9.

34. Shiu P, De Souza-Zaroni WC, de Eduardo CP, Youssef MN. Effect of feldspathic ceramic surface treatments on bond strength to resin cement. Photomed Laser Surg 2007;25:291- 6.

35. Melo RM, Valandro LF, Bottino MA. Micro tensile bond strength of a repair composite to leucite reinforced feldspathic ceramic. Braz Dent J 2007;18:314-9.

36. Guler AU, Yilmaz F, Yenisey M, Guler E, Ural C. Effect of acid etching time and a self-etching adhesive on the shear bond strength of composite resin to porcelain. J Adhes Dent 2006;8:21-5.

37. Guler AU, Yilmaz F, Ural C, Guler E. Evaluation of 24- hour shear bond strength of resin composite to porcelain according to surface treatment. Int ] Prosthodont 2005; 18:156-60.

38. Akova T, Yoldas O, Toroglu MS, Uysal H. Porcelain surface treatment by laser for bracket-porcelain bonding. J Orthod Dentofacial Orthop 2005;128:630-7.

39. Akyıl MS, Yılmaz A, Karaalioğlu OF, Duymuş ZY. Shear bond strength of repair composite resin to an acid-etched and a laser-irradiated feldspathic ceramic surface. Photomed Laser Surg 2010;28:539-45.

40. Estafan D, Dussetschleger F, Estafan A, Jia W. Effect of prebonding procedures on shear bond strength of resin composite to pressable ceramic. Gen Dent 2000;48:412-6.

41. Neis CA, Albuquerque NLG, de Souza Albuquerque I, Gomes EA, de Souza- Filho B, Feitosa VP, Spazzin AO, Bacchi A. Surface treatments for repair of feldspathic, leucite- and lithium disilicatereinforced glass ceramics using composite resin. Braz Dent J. 2015;26:152-5.

42. Lacy AM, La Luz J, Watanabe LG, Dellinges M. Effect of porcelain surface treatment on the bond to composite. J Prosthet Dent 1988;60:288-91.

43. Kara HB, Dilber E, Koç O, Ozturk AN, Bulbul M. Effect of different surface treatments on roughness of IPS Empress 2 ceramic. Laser Med Sci 2012;27:267-72.
44. Keller U, Hibst R. Experimental studies of the application of the Er:YAG laser on dental hard substances: light microscopic and SEM investigations. Lasers Surg Med 1989;9:345-51.

45. Shiu P, De Souza-Zaroni WC, de Eduardo CP, Youssef MN. Effect of feldspathic ceramic surface treatments on bond strength to resin cement. Photomed Laser Surg 2007;25:291- 6.

46. Schmage P, Nergiz I, Herrmann W, Ozcan M. Influence of various surface-conditioning methods on the bond strength of metal brackets to ceramic surfaces. Am J Orthod Dentofacial Orthop 2003;123:540-6.

47. Stübinger $S$, Homann $F$, Etter $C$, Miskiewicz $M$, Wieland $M$, Sader R. Effect of Er:YAG, $\mathrm{CO}_{(2)}$ and diode laser irradiation on surface properties of zirconia endosseous dental implants. Lasers Surg Med 2008;40:223-8.

48. Cavalcanti AN, Pilecki P, Foxton RM, Watson TF, Oliveira MT, Gianinni M, Marchi GM. Evaluation of the surface roughness and morphologic features of Y-TZP ceramics after different surface treatments. Photomed Laser Surg 2009;27:1-7.

\section{Yazışma Adresi}

Dr. Öğr. Üy. Hatice ÖZDEMİR

Atatürk Üniversitesi,

Diş Hekimliği Fakültesi,

Protetik Diş Tedavisi AD, Erzurum

TIf: 04422311783

e-mail: dentist_hatice@hotmail.com 